\title{
Intellectual Property Policy, Legal Framework and Problems of the System for Finding Borrowings in Scientific Works
}

\author{
Orobinskaya V.N. \\ Department of Food Technology and Commodity Science, \\ School of Caucasus Hospitality \\ Institute of Service, Tourism and Design \\ North-Caucasus Federal University \\ Pyatigorsk, Russia \\ orobinskaya.val@yandex.ru \\ Galdin E.V. \\ "Design" Department, Engineering Faculty \\ Institute of Service, Tourism and Design \\ North-Caucasus Federal University \\ Pyatigorsk, Russia \\ galdin@list.ru
}

\author{
Pachina N.N. \\ The Department of Sociology \\ Lipetsk State Technical University \\ Lipetsk, Russia \\ pachina_2017@mail.ru
}

\author{
Pachin A.R. \\ Faculty of Transport Engineers \\ Lipetsk State Technical University \\ Lipetsk, Russia \\ pachina_2017@mail.ru
}

\begin{abstract}
The innovative development of the country is based on intellectual property, which contributes to the development of the country's economy and the achievement of national advantages in the scientific and technical sphere over other countries. One of the promising forms of intellectual property is a scientific publication - the result of scientific and practical activities of scientists conducted over several years. Plagiarism of copyright ideas poses a serious threat. In order to detect "incorrect borrowings", the authors considered the use of existing licensed programs Antiplagiat. VUZ, Turnitin (iPardigms company) and others, allowing to determine "incorrect borrowings" based on the method of comparing source text with pages on the Internet and internal databases, both individually and in combination. The article reveals the legal foundations of the borrowing detection system, analyzes the problems of the borrowing detection system, proposes an algorithm for researching the borrowing detection system in the direction of the effectiveness of scientific research verification, identifies universal competencies for implementing the borrowing detection monitoring system.
\end{abstract}

Keywords-legal framework; borrow detection; electronic borrow detection; research

\section{INTRODUCTION}

The innovation development strategy of Russia and other countries of the world community is strictly focused on intellectual property (IP). Intellectual property is the foundation that embodies the modernization and technological development of the country's economy and the achievement of national advantages in the scientific and technical field [1].

\section{LITERATURE REVIEW}

Intellectual property, which has scientific and technical value, is represented not only by inventions, utility models, computer programs, but also by scientific publications, which are often the result of scientific and practical activities of scientists over several years.

As noted in their work A.A. Molchanov and E.S. Afanasyeva: "The role that is assigned in the public life of intellectual property is comprehensive and contradictory. $\langle\ldots\rangle$ Its versatility finds its manifestation in private and public interests, especially in the world of science, culture, education and art..." [3]

"The organization of intellectual property is a model being developed, aimed at theoretical understanding, normative fixing, revealing in the legal text the regular relationship of the structural elements of all civil law institutions ..." [3].

The provision on the protection of IP is enshrined in Article 44 of the Constitution of the Russian Federation [2].

According to paragraph VIII Art. 2 of the 1967 Convention the definition of "intellectual property" covers a list of rights relating to literary, artistic and scientific works, etc. $[2,3,4]$. Scientific publications related to intellectual property are of scientific interest. 
databases, etc.) and the chaotic, variable space of the rest of the global network ..." [5].

The complexity is connected with the fact that, as $\mathrm{Yu} . \mathrm{V}$. Chekhovich, in his works, and, as the analysis showed due to the imperfection of the detection systems and the high cost of the licensed software product, not all journals from the list of peer-reviewed scientific periodicals, especially when considering scientific publications in 2013-2014. were able to use in their daily activities a licensed system with the additional capabilities of detecting "incorrect borrowing".

This led not to a decrease in "bad borrowing" at this stage, but to a decrease in the flow of scientific publications and dissertations. When checking for originality, as plagiarism, the system noted the "methods" of analysis and previously published works in the journals of the Higher Attestation Commission, which are prerequisites for the defense of a candidate or doctoral dissertation.

In 2013 - 2014 turned out to be peak - more than 30 people were deprived of academic degrees, 602 dissertation councils were closed and suspended, one of the main reasons was a poor-quality examination of originality.

Despite the number of publications devoted to this problem, both in the field of digital technologies and in academic fields, the issue remains relevant and open.

Added additional factors that exacerbate these problems. According to the research of V.I. Shinkarenko, E.S. Kuropyatnik, an additional classification of "incorrect borrowings" appeared (Table I.) [6, 7, 8].

TABLE I. CLASSIFICATION OF "INCORRECT BORROWING" [7].

\begin{tabular}{|c|c|c|}
\hline \multicolumn{2}{|c|}{ "Inappropriate borrowing" (plagiarism) } \\
\hline By technical means & $\begin{array}{c}\text { By type of } \\
\text { "camouflage" of } \\
\text { plagiarism }\end{array}$ & By volume \\
\hline
\end{tabular}

A serious problem is presented by the types of plagiarism in magistrates' works, the special plagiarism of the source computer code, not determined by the "Antiplagiat. VUZ" program, and scientific work with masking elements (Table II.)

TABLE II. CLASSIFICATION OF “CAMOUFLAGE” PLAGIARISM

As noted by Z.M. Khachetsukov “... The main reasons are the anonymity of use and placement, the high dynamics of the environment. The ease of copying and placement ... "[3]

The result is a mass of duplicate resources. When conducting an expert analysis in the licensed program "Antiplagiat. VUZ" of an extended report and an in-depth study of scientific material, very often an entry "from an unknown source" appears. The source of the original text becomes uncertain and authorship is lost. When re-checking scientific material, the situation may worsen.

One cannot but agree with Z.M. Khachetsukov "At the same time, there is no border between the logically structured structures of information resources (digital libraries,

\begin{tabular}{|c|c|c|c|}
\hline \multicolumn{4}{|c|}{ "Camouflage" plagiarism } \\
\hline $\begin{array}{c}\text { Using } \\
\text { unprintable } \\
\text { symbols }\end{array}$ & $\begin{array}{c}\text { Spelling errors } \\
\text { with a certain } \\
\text { probability }\end{array}$ & $\begin{array}{l}\text { Replacing numbers } \\
\text { in words }\end{array}$ & $\begin{array}{l}\text { Additional } \\
\text { backup row }\end{array}$ \\
\hline
\end{tabular}

In order to obtain more complete information, an additional check was carried out on borrowings on the Google Scholar and Google Books databases, showing borrowings that were not determined using licensed programs [10].

Of interest is the possibility of combining, and the use of other systems for determining the borrowings of scientific 
The implementation of the Order of the Ministry of publications published in English, for example, the borrowing system Strikeplagirism.com - the anti-plagiarism system developed in Poland, a feature of this system is

- "Alarm" function - to indicate attempts to place text analysis with "incorrect borrowings";

- Identification of similarities using algorithms based on $\mathrm{N}$-grams, linguistic analysis;

- Performs similarity analysis in many languages.

The disadvantage is the lack of support for the Russian and Ukrainian languages.

Maybe a combination with similar systems will improve the licensed programs of domestic manufacturers and will add a touch of modification to the most common and demanded in the Russian market system "Antiplagiat. VUZ".

Moreover, an extended report does not show nonlegitimate or legitimate borrowings; true authorship is difficult to establish.

In addition, there is still an acute issue related to selfplagiarism (to what extent and in what way studies should be identified.

These issues are relevant and require a planned and immediate solution at different levels: theoretical and methodological, regulatory, technological.

System-forming approaches in the borrowing detection system - queuing theory, decision theory, acmeological approach, systemic approaches.

\section{RESULTS}

Queuing theory is the basis for modeling the queuing process when checking scientific work for plagiarism. The theory of decision-making studies the patterns of choice by subjects of ways to solve various kinds of problems when using electronic borrow detection systems. The borrowing detection system is considered as a system of multi-level functioning from the position of a systematic approach.

The acmeological approach allowed:

1. To examine users of electronic systems for detecting borrowings in the provision of services as stakeholders.

2. To reveal the potential and current opportunities for the introduction of electronic borrow detection systems.

3. The optimization principle ensured the optimal use of electronic borrow detection systems.

4. The operational-technological principle made it possible to develop certain algorithms for the functioning of electronic borrowing detection systems.

5. The principle of modeling allowed us to develop a model for detecting borrowings. The theory of professional acmeology has shown professional areas of self-improvement in scientific and other fields based on the implementation of borrowing detection technology..." $[11,12.13]$.
Education and Science No. 636, which deals with the verification of work on the volume of borrowings, required in a short time the creation and implementation of a system to control the volume of borrowings in educational institutions and determine the normative percentage of detection of borrowings. This requires the development of regulatory documents, which would determine the percentage of originality of scientific work. Normative documents regulate the verification of work on the detection of borrowings and the establishment of a normative percentage of originality, however, the problem remains of developing common criteria for the originality of educational products of intellectual activity. Unified criteria were developed at the Lipetsk State Technical University in the system documentation: standard on the system for controlling the volume of borrowings, a university-wide regulation on expert assessment of the volume of correct borrowings, and methodological instructions on controlling the volume of borrowings of final qualifying works.

According to research N.N. Panchina: "The technological component, the actual development and implementation of borrowing detection technology can be divided into several components.

1. The methodological component is the development of borrowing detection techniques.

2. Organizational component - the distribution of powers and responsibility for the control and examination of documents on the amount of correct borrowing. The subjects of the educational process of an institution are included to varying degrees in the process of controlling the system of borrowing volume. The share of responsibility of each entity is noted in the matrix of the distribution of powers and responsibility in the system of control of the volume of borrowings.

3.Expert component. For the examination, it is important to determine the normative percentage of correct borrowings in documents.

Technological aspects for determining the normative percentage of originality are associated with a certain algorithm.

1. Development of methods for determining the normative percentage of originality.

2. Diagnostic monitoring of determining the normative percentage of originality of various types of work in the areas of specialist training.

3. An expert assessment of the results of diagnostic monitoring for the purpose of harmonizing and establishing a normative percentage of originality.

4. Determination of the normative percentage of originality of various types of work using the borrowing detection system and correlation with the established normative percentage of originality.

5. Adjustment and further strategic line to determine the normative percentage of originality of various types of work. 
- originality and independence of documents of the organization;

- the presence of correct and unlawful borrowings in the documents of the organization;

- the monitoring procedure, examination and control on the volume of borrowing documents;

- the procedure for conducting the state final certification for higher education educational programs - undergraduate programs, specialty programs and master's programs in terms of control over the volume of borrowings of GQW (graduation qualification work).

Competencies should be laid down in the Regulation on expert evaluation of the amount of correct borrowing, which establishes:

Entering and editing the list of organizational structures.

6. The technological component. Providing responsible text of the work in electronic form. Downloading documents of employees and student work in electronic systems. Selfexamination of works by those who performed them for compliance with the approved requirements on the limits of permissible borrowing. Providing self-test data on the amount of borrowing to responsible persons. Verification of work by persons responsible for monitoring the volume of borrowings for compliance with the approved requirements on the limits of permissible borrowing. Providing data on the verification of the amount of borrowing to responsible persons. Examination of documents based on reports of the EBDS on the amount of correct borrowing and drawing up expert opinions. Monitoring the verification of documents for borrowing. Determining the order (strategy) of increasing the percentage of originality of work. Control over the order (strategy) of increasing the percentage of originality of work. Examination of student appeals. Indexing of works that have passed examination on the volume of borrowings and have received a positive assessment to form a collection of university work.

7. The control component contains the following components. Preparation of a report to the responsible person on the introduction and operation of electronic systems in operation. Analysis of the effectiveness and quality of writing and protecting works in accordance with regulatory indicators of borrowing volume. Preparation of a report on the control of documents on the volume of borrowings and preparation of recommendations on optimizing the verification process of works on borrowings..." $[11,12,13,14]$.

\section{CONCLUSION}

To implement a system for controlling the volume of borrowing, certain competencies are required. We will disclose those aspects that are reflected in regulatory documents.

Competencies should be consistent with the standard of the borrowing volume control system, where requirements for:

- the volume of borrowing documents of the organization: the work of the faculty, students, university documentation;
- goals and objectives of expert assessment of the amount of correct borrowing in documents;

- $\quad$ structural and substantive norms of correct borrowing in documents;

a single procedure for expert evaluation of correct borrowings in documents.

Competencies should be reflected in the Methodological instruction on control over the volume of borrowings of final qualification works, which sets out the requirements for:

- originality and independence of the GQW (graduation qualification work) of students;

- the presence of correct and illegal borrowing in the GQW (graduation qualification work) of students;

- the procedure for conducting state final certification for higher education educational programs - undergraduate programs, specialty programs and master's programs.

The indicated requirements make it possible to single out borrowing detection monitoring system: regulatory competence is responsible for knowing the norms in the field of borrowing detection; diagnostic competence in the field of borrowing detection monitoring system allows diagnosing the level of implementation of the borrowing detection monitoring system; expert competence - to give an expert assessment of the volume of correct borrowing in documents; controlling competence - to control the process of detecting borrowings; research competence of originality and independence of documents - determination of the normative percentage of these categories in relation to various types of documents.

\section{References}

[1] Ob utverzhdenii Strategii innovatsionnogo razvitiya Rossiyskoy Federatsii na period do 2020 goda: Rasporyazhenie Pravitel'stva RF ot 8 dekabrya 2011 g. № 2227-r. Sobranie zakonodatel'stva RF. 2012, 1, pp. 216. the main competencies for the implementation of the 
[9] Kakkonen, T., Myller N. AntiPlag - A Sampling-based Tool for Plagiarism Detection in Student exts. The Proc. of the 8th European Conference on E-learning (29.10-30.10.2009). Bari, Italy. 2009, pp. 287-293

[10] Mozgovoy, M. Automatic Student Plagiarism Detection: Future Perspectives / M. Mozgovoy, T. Kakkonen, G. Cosma. J. of Educational Computing Research. 2010, vol. 43, 4, pp. 511-531. DOI: 10.2190/ec.43.4.e

[11] Panchina N.N., Blinnikova O.N., Pachin R.G. Printsipy razvitiya ehkspertnoy kompetentnosti obnaruzheniya zaimstvovaniy. Ehlektronnye biblioteki. 2017, vol. 20, 5, pp. 244-353.

[12] Panchina N.N., Chernykh L.A., Blinnikova O.N., Pachin G. R., Pachin A.R. Osnovnye metodicheskie podkhody i printsipy raboty $s$ ehlektronnymi sistemami obnaruzheniya zaimstvovaniy// Pedagogicheskaya informatika. 2018, 2, pp.107-113.

[13] Alexsandr S. Kuznetsov. Russian Professor's meeting. Russian Journal of Physical Education and Sport. 2019, 14(1), pp. 17-22. DOI: 10.14526/2070-4798-2019-14-1-18-24

[14] Shebzukhova T.A., Vartumyan A.A., Orobinskaya V.N. Problema "nekorrektnykh zaimstvovaniy" pri napisanii nauchnykh statey i metody ee resheniya// Pedagogicheskaya informatika. 2018, 2, pp. 1-7-113 